\title{
American Historical Association: U.S. Labor History
}

\author{
John B. Jentz \\ Northern Illinois University
}

Labor historians were poorly represented on the program of the AHA's 1991 annual meeting held in Chicago in December. Although numerous panels dealt with issues of interest to labor historians, the papers were usually presented by scholars of cities, immigration, race, and gender.

In a panel entitled "Women's Work and Politics in the United States," Paula Baker and Elizabeth Faue evaluated the current state of women's history and proposed new lines of interpretation. Baker's paper - "The Problem of Marginal Differentiation: Difference, Agency, Identity, and Tailfins in the Study of Women's History"-called for new categories in analyzing the role of women in politics, instead of the stress on women's agency and the search for identity that has characterized so much scholarship. She suggested that the ideas of political action and political interests would help scholars of women's political activity move beyond the concept of maternalism to analyze the differences among women in the political arena.

Elizabeth Faue argued that, within the triad of concepts-race, gender, and class-currently preoccupying historians, class gets subsumed under discussions of race and gender, a situation reflecting the contemporary state of feminist socialism. Her paper, "Divisions and Revisions: History and the Politics of Women's Work since the Sears Case," called for a new discussion of class in women's history focusing on the nature of social reproduction. She noted E. P. Thompson's insight that people first encounter class as children, not as workers. Looking at the life cycle could reveal how class, gender, and race intersect in the lives of individuals.

Karen Sawislak, Carl Smith, and Janice L. Reiff discussed issues of ethnicity, gender, and class in their panel, "Whose City? Whose Country? Social Conflict and the Definition of an Urban Order in Late Nineteenth-Century Chicago." Sawislak concentrated on the relief efforts of middle-class women after the Chicago Fire of 1871; Smith on how the Haymarket Affair influenced the public rhetoric describing urban order; and Reiff on the social and political life of ethnic neighborhoods around the Pullman factory before the great strike of 1894. Smith and Reiff's work was particularly pertinent to labor issues. Smith's paper analyzed how the contestants in the dispute about Haymarket loaded new and contrasting meanings on key words of public debate, such as "foreign," "manhood," and 
"natural." Reiff's paper defined a "broader neighborhood" beyond but including the town of Pullman that constituted the effective locus of local political power in the area. She described three parades in 1886, 1892, and 1894 to present the evolution of this broader neighborhood.

Although part of another panel, Richard Schneirov's paper on Chicago, "From Political Collective Bargaining to Private Collective Bargaining: The Building of the 1893 Chicago World's Fair as a Turning Point in Labor-Capital Relations," can be discussed in this context. Schneirov was perhaps the only panelist at the convention to address the subjects of unions and strikes. His paper made three major points: First, during the 1870 s and 1880 s, segments of Chicago labor relied upon political alliances with local government to attain something like parity in their economic struggles with employers. Second, the Haymarket events, far from destroying the labor movement, were part of an extended and successful upheaval that continued into the 1890s. Finally, during the building of the World's Fair, this growing labor movement combined with a new social reform mood among the middle classes to win a hedging commitment to collective bargaining in the private sphere without reliance on the local state.

One of the liveliest panels was on "The Urban 'Underclass': Historical Perspectives." Robin D. G. Kelley spoke on "Underclass Struggle: Survival and Opposition among the Black Urban Poor in Birmingham, Alabama, 1929-1963." He contrasted the needs and political struggles of working- and middle-class blacks and sketched a "hidden politics of the poor" in the struggles of everyday life. In her paper - "Southern Diaspora: Origins of the Northern "Underclass" " Jacqueline Jones compared the social histories of Appalachian whites and southern blacks in the lower Midwest, particularly in Ohio. The limited but real successes of poor whites illustrated how a culture of poverty did not severely constrict the lives of rural southerners in the North. She stressed how the residential mobility available to poor whites resulted in substantial advantages, such as better schools and city services. Thomas J. Sugrue spoke on "Empowering the Poor: The State. Community Activism, and Housing in a Black Detroit Neighborhood, 19351950." His paper was a case study in the politics of federal housing policy. Poor blacks made alliances with New Deal federal bureaucrats to win a limited victory in maintaining the single-family homes that had been slated for "redevelopment."

A panel on the "Political Economy of Cultural Revolution in the United States, 1890-1920" was chaired by Martin J. Sklar and featured Ann Fabian and James Livingston. In "Popular Truths: The Circulation of Gossip," Fabian analyzed the publishing enterprises of Bernar McFaden in the first three decades of the twentieth century, particularly his magazines Physical Culture and True Story. The latter had an audience among the wives of skilled workers; it linked gossip, the movies, and sexuality to create a working-class version of bourgeois consumer culture. According to Livingston, the real title of his paper, in contrast to the published one, was "The Political Economy of Pragmatism." He situated the philosophy of pragmatism within the emergence of corporate capitalism. One of 
his goals was to propose a philosophical basis for a critique of the social criticism of Christopher Lasch and Lewis Mumford.

\title{
American Historical Association: Latin American and European Labor History
}

\author{
Leslie Ann Schuster \\ Wabash College
}

The December 1991 meeting of the American Historical Association included few panels on European labor history. At a session on "International Economies and Indian Labor in Turn-of-the-Century Latin America," Peter Linder (Washington State University) investigated Indian forced labor in Venezuela. Labor shortages induced hacendados in the Sur del Lago zuliano to enslave the Guajiro Indians. Although Indian slaves became "the mainstay of the agricultural labor force" by the 1920s, state officials regarded slavery as necessary for economic development and assimilation and chose only to minimize abuses. Erick D. Langer (Carnegie Mellon University) examined two contrasting labor systems in Argentina: The Chaco tribes were coerced to work on the sugar cane fields while the Chriguano Indians chose to migrate to the plantations. Coercion proved ineffective among the Chiriguanos but material enticements and political oppression imposed by new settlers led them to migrate. Michael Stanfield (University of New Mexico) also argued against characterizing Indians as victims of the international economy. While the search for rubber and quina in northwestern Amazonia dictated forced labor and transformed material and social relations, Indians did not remain passive victims. Instead, the culture and resources of indigenous tribes shaped their adaptation. Some tribes participated in trade, others used "primeval traditions to rescue culture," yet others attacked industrial outposts, and those tribes diminished in number by European diseases stole women members of other tribes to enhance social status.

The panel on "The International Character of Italian Immigrant Radicalism, 1870-1939" examined how political experiences in Italy shaped the activity of Italian immigrants in the United States. Fraser M. Ottanelli (University of South Florida-Lakeland) illustrated the relationship between workers' political activity in Italy and their antifascism in the United States. An analysis of the profession, political affiliation, and age of immigrants points to a correlation between labor and political activity in Italy and participation in the antifascist movement upon immigration. Ottanelli underscored the need for a generational examination of immigrant radicalism by showing that the antifascism of Italians raised in the U.S. in the 1930s emerged from different political experiences. Patrizia Sione (State 